\title{
Analysis of Problems and Countermeasures of Big Users' Direct Power Purchase in China in the Perspective of Stakeholder Theory
}

\author{
Li-Yuan $\mathrm{Cao}^{*}$ \\ School of Humanities and Social Sciences, North China \\ Electric Power University, Baoding, P.R. China, 071003 \\ Email:caoliyuan1983@163.com,
}

\begin{abstract}
-with the continued development of electricity marketization, big users' direct power purchase has been seen as the best starting point of the power system reform. In the perspective of stakeholder theory, refer to foreign successful experience of direct power trading, analyze the problems of big users' direct power purchase, and thereby put forward some guiding suggestions. Through analyzing, the successful experience of direct power trading in developed countries includes perfecting laws and regulations in advance, relaxing the users' options gradually, perfecting the electricity price system; Problems of big users' direct power purchase in China includes that laws and regulations, big users' market access mechanism, trading rules, supervisory mechanism and electricity price system are incomplete. Finally, offer some proposals in the perspective of stakeholder theory: perfect relevant laws and regulations, confirm big users' access conditions moderately, standardize the trading rules, establish an effective supervision mechanism, accelerate to adjust the electricity price system.
\end{abstract}

Keywords- Electricity marketization, Big users' direct power purchase, Stakeholder theory, Problems, Countermeasures.

\section{INTRODUCTION}

Big users' direct power purchase refers to that the big users and independent power generation enterprises sign bilateral power purchase contract to complete power trading after consultation, which is a special purchase model. It means that independent power producers are not only chosen directly by big users, but also have the rights to choose users. At the same time, power grid companies are no longer monopolies for electricity trading activities. ${ }^{[1]} \mathrm{In}$ China, the "big users" is a relative concept, which would be replaced by unified "electricity customers" or "power users" as the eligibility threshold was reduced gradually. Abroad, there is no the term "big users' direct power purchase", because the fact is the electricity market adopts the model of bilateral trade geared to the needs of all users.

In 2002, Power Institutional Reform Scheme (V text) marks the start of China's power market reform. So far, the separation of power producers and power grids companies has been completed basically, and the separation of power main business and power supplementary business is going on orderly, and it has been recognized that power transmission and distribution should not be separated, so direct power purchase model has become the best starting point for reform. Some relative statistics show that it is the

\author{
Qing Li \\ School of Humanities and Social Sciences, North China \\ Electric Power University, Baoding, P.R. China, 071003 \\ Email:1224974273@qq.com
}

phase of regional power generation side market reform from 2002 to 2006, and it is the phase of direct power purchase pilot from 2004 to 2009 , and now the direct power trading reform instead of regional power generation side market reform has become the main direction of China's power market reform.

\section{STAKEHOLDER THEORY}

Stakeholder theory was developed gradually in the United States and Britain from the 1960s. Until 1984, Freeman came up with stakeholder theory and the definition of stakeholder clearly in Strategic Management: A Stakeholder Approach, and his opinions have become most representative opinions. Stakeholders are all individuals and groups which have interests relationship with enterprises' production and business activities and consequences, and stakeholder theory means that the enterprise operators and managers should balance the interests of every stakeholder when carrying out management. Because almost any activity needs to deal with interpersonal relationship, stakeholder theory has been extended and applied to many other areas for recent years, such as organization management and society reforms.

\section{FOREIGN SUCCESSFUL EXPERIENCE OF DIRECT POWER TRADING}

In terms of direct power trading, foreign governments' policy measures has important reference value, generally including the following opinions:

\section{A. Relative Laws And Regulations Have Been Released In Advance}

In the implementation of power market reform, all countries have modified or developed laws and regulations related to power industries, ensuring the smooth progress of the reform. Opening sale side market namely that allow the users to choose power sellers freely is one of the important contents, including clearing rights and obligations of users and sellers, concretizing the course of loosening control of big users' options, etc.

\section{B. The Users' Options Have Been Liberalized Gradually}

Liberalizing the big users' options is common experience of liberalizing power sale market internationally, and the most countries that carried out the power market 
reform liberalized users' options according to the voltage level and capacity of electricity utilization, step by step and phase by phase. On the specific process, the majority of the countries liberalized users' options successfully from big users to small users.

\section{Price System Is Relatively Perfect}

Before liberalizing the power sale market, nearly all the countries have formulated independent power transmission and distribution price system, or have cleared about power transmission and distribution pricing mechanism, and this laid price foundation for power grid companies to open to all customers fairly. The price system have some other features: When different users use the same grid, the power transmission and distribution price are consistent; The price structures of all types of users are reasonable, and there is no cross-subsidy costs basically.

\section{Problems of Big Users' Direct Power Purchase in China}

Reform is a process of redistribution of interests, and big users' direct power purchase model is not only directly related to the interests of power producers, power grids companies and power users, but also indirectly affects the interests of the non-users and overall society. The reason why foreign direct power purchase model could be implemented efficiently is because that the market plays a decisive role in the allocation of resources. It is just the mature market-based mechanism that makes the complex and conflicting interests become simplistic, namely that the market activists make final choices after rational analysis, and all stakeholders are equal in the game.

Based on the pilot situation, there is a risk in our direct power purchase trading that power producers are unilateral at a disadvantage to electricity purchasing enterprises; power grid enterprises bear the transmission costs and impact from power generation enterprises. In a word, demand side is positive, while power generation side and power sale side markets are difficult to activate. So, in the case that only one side benefits, power direct trade has been in trouble. Grasping the interests objectives of the stakeholders and coordinating the relationship among various interests have very important significance practically for promoting power direct trading and the power marketization effectively. Because the power system reform is the result which the government chose, so the existing problems are mainly policy issues at present. Incomplete policies lead to interests coordination channel blocked, specifically including the following points:

\section{E. Laws and Regulations are not Complete}

The interests of stakeholders of big users' direct power purchase must be safeguarded by the electricity laws and regulations. In China's current laws, the direct power purchase prohibitions is the biggest obstacle which big users' direct power purchase has been confronted with. For example, Electricity Law Article 25 and Electricity supply and use regulations Article 8 clearly regulates that one power supply area can only own one power supply organization. So the appearance of big users' direct power purchase actually violates Electricity Law seriously, and modifying the Electricity Law has become an inherent requirement of power system reform. In addition, with respect to the power grid scheduling management, price setting, ancillary services, etc, new laws are needed, while existing relevant laws and regulations are not perfect, so big users' direct power purchase is contradicting with the existing laws and regulations, resulting in a lot of inconvenience and disputes in reform practice.[3]

\section{F. Relevant Policies Are Not Complete}

\section{(1) The Market Access Provisions of Big Users} are Imperfect.

In accordance with China's regulations, big power users are those big industrial users whose voltage level is at 110 $\mathrm{kV}$ and above and conform to national industry policy. ${ }^{[4]} \mathrm{It}$ can be said that the definition is quite imperfect, and the selected dimensions are too few, and it even could cause market become unfair, as some energy-intensive industries could get access. In addition, according to the experience of foreign countries, the big users' options should be liberalized step by step instead of keeping the same all the time. Thereby, how to clearly define big users, and how to make the standards flexible and universal to adapt to the actual situation in different regions at different times is very crucial.

\section{(2) The Trading Rules are not Complete.}

Our direct power purchase market lacks of systematic operating rules. Big users and grid companies need to sign transmission contracts and auxiliary services contracts, and grid companies are obliged to provide transmission services to big users. However, grid companies are not only responsible for the fulfillment of contractual obligations, but also need to ensure grid secure. ${ }^{[5]}$ In this regard the grid companies are at a disadvantage. Grid accidents are uncertain, so the loss was not little in case it happened; because the contract is not perfect, the decline of power supply would damage the grid companies' interests. The power surplus and deficiency that are similar with the condition above need to be solved too. In addition, direct power purchase is required to sign contracts, including power transmission contract between users and grids enterprises, and power supply contract between users and power producers. But there is no unified contract text, leading to contract terms omissions, and it is difficult to get contracts generally recognized by stakeholders, which resulted in inconvenience when call to account and coordinate disputes.

(3) The regulatory Mechanism Is Inadequate.

The high efficiency of big users' direct purchase relies on market players' own faith and the insurance system that trade organizations established. Effective regulations is significant in avoiding the transaction risk, for example, the Nordic electricity market wasn't affected by the United States basically in the 2008 financial crisis, and this lies in its strict and effective supervision and risk-preventing system. Now, electricity regulatory agencies audit involved enterprises annually, and release trading results information of big users' direct power purchase monthly.[6] However, 
because China's power market reform is still at exploratory stage, the supervision for trading process of direct power purchase is not enough. The entire transaction process needs to be supervised, thus inspecting stakeholders access, normalizing price system, promoting fair competition all belong to the range of regulation. The current regulation lacks of more detailed requirements, and the regulatory agencies lack of the ability to grasp market trends and prevent risk, and regulatory measures are simplex.

\section{G. Tariff System is not Completed}

Big users' direct power purchase involves overall reform of price system. Firstly, the power purchase agreement is reached between big users and power producers, while the trading must rely on the grid transmission and ancillary services of grid companies to complete. The transmission and distribution price system reflect costs of utility transmission and ancillary services. Secondly, as a government's macro-control tool, the price includes many policy factors, generating serious cross-subsidy.[7] Based on the pilots situation, big users' and power companies' additional revenue was achieved by evading social responsibility, including substantial tariff cross-subsidization costs. If the price keeps the same, these costs will be fully passed on to the grid companies, forming heavy burden on them.

\section{SOME GUIDING SUGGESTIONS TO PROMOTE BIG USERS' DIRECT POWER PURCHASE EFFECTIVELY IN CHINA}

Only by guaranteeing and enhancing stakeholders' interests, can we continue the reform smoothly. In order to coordinate and balance the interests of so many parties and break the bottleneck of direct power purchase, we put forward the following principle recommendations:

\section{A. Perfect Relevant Laws and Regulations}

We must accelerate the revision of Electricity Law and Regulations, adding detailed contents of direct power purchase reform to its rules. In addition, we should enhance the positioning of direct power purchase in the aspect of law, and regard direct power purchase as a target of power system reform. In a word, legislation is an urgent task.

\section{B. Confirm big Users'Access Conditions Moderately}

First of all, we should define the range of big users precisely from various angles and make very detailed rules in electricity voltage levels, national industrial policy, electricity load stability, emissions, energy consumption per unit of output and other aspects, and avoid the unqualified enterprises taking advantage of legal loopholes. In addition, since the levels of power construction and economic development of all regions are uneven, we should adjust big users' criteria appropriately aimed at different regions within the law. We should emphasis specially that the final purpose is to optimize the allocation of resources, transform the economic growth mode and upgrade the industrial structure, so we must implement the national industrial policy and environmental policy firmly, and say no to eliminated and restrained industries. In this way can we promote the sustainable development of direct power purchase and be in line with social interests.

\section{Standardize the Trading Rules}

Once the grid obstruction occurs, power companies have to cut the load, including big users' demand of course. Load cutting standard must be determined by grid companies and big users in advance. For the problem of surplus and deficiency of electricity, two sides should attach the concrete solutions to the contract terms after accounting in order to ensure the fundamental interests of buyers and sellers. Meanwhile, the government should strengthen the study of contract form and terms, and put the power purchase and sale contract model into trail use, then focus energy on the terms which have uncertainties and controversial during execution.

\section{Establish an Effective Regulation Mechanism}

Referring to the foreign successful experience in power market regulation, we must accelerate to cultivate and perfect regulation mechanism combining with China's national conditions. Firstly, supervise strictly stakeholders' access conditions, including big users' and power companies' to maintain orderly competition in power generation sector and ensure high efficiency of market allocation of resources; Secondly, supervise the pricing behavior of stakeholders, and assure the legitimacy and normative of generation, transmission, distribution, and consumption four steps through tariff regulation, China don't have the condition of market-based pricing after all; Finally, supervise competition and trading of stakeholders to promote healthy competition and avoid risk, forcing every side to strengthen management, improve technology and improve efficiency constantly. In order to achieve effective supervision of the entire transaction process, we need reliable technical supports, such as improvement and refinement of regulations, and the improvement of risk-preventing mechanism of supervisory agencies, and policies, prices and other multi-pronged approaches.

\section{E. Accelerate to Adjust the Electricity Pricing System}

As one of the power market players, big users should bear risk in power trading process. And based on the pilots' situation, big users simply enjoy low tariff privileges. To accelerate price reform, the establishment of an independent and reasonable power transmission and distribution mechanism is very important. We could release a two-part power transmission and distribution pricing system which distinguishes voltage into grades, taking the grid construction and operating costs and reasonable return and the existing tariff into consideration. ${ }^{[8]}$ At the same time, it is important to study the solutions to cross-subsidy problem, and articulate that big users must bear the cross-subsidy costs. In the early, the cross-subsidy costs could be considered into the power transmission and distribution price, and the big users could assume the cross-subsidy obligation by paying power transmission and distribution price; When the time is right, we could choose explicit 
subsidies instead of implicit subsidies gradually, adding the costs of cross-subsidy into purchase price. In short, cross-subsidy should be apportioned fairly among all stakeholders.

\section{CONCLUSION}

Direct power trading is a key step to liberalize power sale side market, so the government will promote the reform to further development unswervingly. As the reform involves law, tariff and many other issues, the adjustment range of stakeholders' interests is wide, therefore we must take full advantage of the pilot opportunity to gain experience, to minimize the burden on all sides. Only when the interests of every stakeholder get balanced and all stakeholders share the achievements of reform and development, can direct power trading and power marketization develop healthily.

With the deep development of power market, the coverage of "big users" will be more and more extensive, the limitation to the trading volume will be loosened little by little. China's power direct trading will step into highly marketable stage following developed countries' track: Various trading modes, including bilateral deals and intensive transactions in the power operation centers; Power supply modes will be diversified, including network mode and line mode; Transaction means is various, including financial transaction and physical transaction. In a word, the power market will operate in an orderly way, and all activities are rules-based. This is a very long and tough way, but an irreversible trend.

\section{ACKNOWLEDGMENT}

This paper is supported by Beijing Energy Development Research Base.

\section{REFERENCES}

[1] Qian SUN, Feng LIU. The Electric Power Industry Reform Mode and Its Enlightenments. Management of Electric Power Demand Side, 2006, 8 (1): 62-64

[2] The state electricity regulatory commission. The Exploration of Big Users' Direct Power Trading and Foreign Electricity Regulation Experience. Beijing: China Power Press, 2008

[3] Hao-Yong CHEN, Sen-Lin ZHANG, Yao Zhang. The Research of Big Users' Direct Power Purchase in Power Market. Journal of Eastern China's Power, 2008

[4] Sen-Lin ZHANG, Yao ZHANG, Hao-Yong CHEN. The Research of Several Crucial Problems of Big Users' Direct Power Purchase. Journal of Eastern China's Power, 2009

[5] Lei ZHAO, Kun GUO. The Existing Problems and Countermeasures of China's Big Users' Direct Power Purchase at Present. North China Electric Power Technology, 2006, 9

[6] Hai-Feng CUI, Sheng-Ye YANG. The Organization and Implementation of Big Users' Direct Power Purchase at the Initial Stage of Power Market Construction. Journal of Shanxi Electric Power, 2009

[7] Jiang-Yi HU, Xi-Ying CHEN. The Discussion of Big Users' direct power purchase. Power Grid Technology, 2007, 31 (24) : 40-45

[8] Ding-Jun GU, Sheng WANG, Neng-Ta CHEN. The Analysis of Several Problems of Big Customers' Direct Power Purchase. Journal of Guangdong electric power, 2010. 